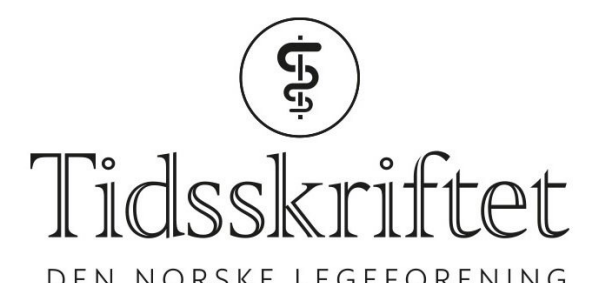

DEN NORSKE LEGEFORENING

\title{
Immunterapi ved sepsis
}

DOKTORAVHANDLINGER

ESPEN WAAGE SKJEFLO

E-post: espenwskjeflo@gmail.com

Hemming av aktivitet i systemene for komplementreseptorer og toll-like reseptorer kan forebygge komplikasjoner ved sepsis i spedgris.

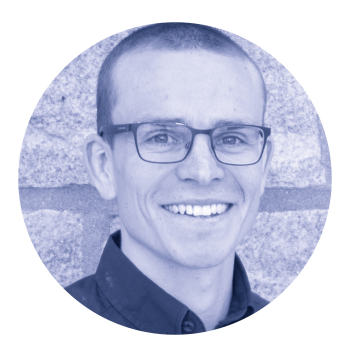

Foto: Børre Arntzen

Immunforsvaret står sentralt i infeksjonsbekjempelsen. Komplementreseptorer og toll-like reseptorer bidrar til bekjempelse av infeksjon ved at de gjenkjenner mikrober og setter i gang betennelsesprosessen. Denne immunresponsen er stort sett til det gode, men noen ganger løper betennelsesreaksjoner løpsk og er mer til skade enn til gagn.

I mitt doktorgradsprosjekt har jeg unders $ø$ kt hvilken betydning hemming av molekyler i systemene for komplementreseptorer og toll-like reseptorer har for sepsisutvikling. Først viste jeg at hemming av disse reseptorsystemene reduserte nivåene av inflammasjonsmarkører i menneskeblod tilsatt bakterier. Dernest viste jeg at hemming ga høyere overlevelse hos spedgris, i en blindet, randomisert, kontrollert studie.

Immunforsvaret spiller en viktig rolle i sepsis. I fremtidig forskning bør man undersøke om profylaktisk og antiinflammatorisk behandling også kan ha betydning ved behandling av sepsis hos mennesker.

\section{Disputas}

Espen Waage Skjeflo disputerte for ph.d.-graden ved Universitetet i Troms $\emptyset$ - Norges arktiske universitet - 28.11.2017. Tittelen på avhandlingen er Harnessing innate immunitycomplement and TLR inhibition in experimental models of gram-positive and polymicrobial bacteremia and sepsis. 
Publisert: 28. mai 2018. Tidsskr Nor Legeforen. DOI: 10.4045/tidsskr.18.0164 (C) Tidsskrift for Den norske legeforening 2020. Lastet ned fra tidsskriftet.no 